immigration to Canada is at present possible only for persons who have close family already here or who possess investment capital. By moving to create immigration opportunities for those who seek to improve their personal or economic opportunities, the temptation on the part of such persons to use the refugee process as a means of entry would be dramatically reduced.

It is right to be concerned about the possibility of abuse of a more humane determination process, but we must be equally mindful of the need to treat genuine refugees in a way that commands both legal and moral respect. The Plaut Report acknowledges this imperative by proposing an effective yet unobtrusive means of controlling fraudulent claims, while minimizing the negative impact of immigration concerns on those who truly seek a safe haven from persecution.

James C. Hathaway is Assistant Professor of Law and Director of Clinical Education, Osgoode Hall Law School of York University.

\begin{tabular}{|l} 
Supreme Court \\
of Canada \\
Requiring Oral Hearings \\
for \\
Refugee Claims \\
The appeals are allowed and the \\
decisions of the Federal Court of \\
Appeal and the Immigration \\
Appeal Board are set aside. The \\
applications of the appellants for \\
redetermination of their refugee \\
claims are remanded to the \\
Immigration Appeal Board for a \\
hearing on the merits in \\
accordance with principles of \\
fundamental justice. \\
The appellants are entitled to \\
a declaration that s. 71(1) of the \\
Immigration Act, 1976 in its \\
present form, has no application \\
to them.
\end{tabular}

\title{
A New Inland Refugee Determination Procedure - A Challenge for Canada
}

The Canadian government must review its inland refugee determination procedure in light of a recent Supreme Court decision requiring the federal government to give all refugee claimants an oral hearing before a decision is made on the merits of their claim. The Plaut Report has been submitted to the Minister of Immigration outlining three models to be considered for a new refugee determination procedure. Amnesty International, the churches, and over 70 refugee/resettlement agencies share the view that the decision made at the initial determination is the most important, given the difficulty of reversing negative decisions once made.

Because the consequences of the determination are serious - the life or liberty of the claimant may be in question - decisions should not remain the sole responsibility of one decision-maker; collegial decision-making leads to a higher quality of decisions because it allows for an exchange of ideas. Consequently, refugee decisions at the first level should be made by a panel of more than one person.

With regard to an appeal, it is essential that redeterminations be dealt with by a decision-making body that is distinct from the entity handling the initial determination; fairness dictates that one does not appeal to the same people that already have decided against one. Though initial determinations will be made throughout the country, the redetermination entity should be centralized in order to ensure consistency of the decision-making procedure. A centralized review can set the standards throughout Canada and ensure that the same criteria are applied to all refugee claimants; it would deal with issues of law and apply accepted refugee criteria if the facts are not in dispute.

The decision-makers on review, not having seen the claimant in person, cannot be expected to second-guess the initial determination regarding the claimant's credibility. Furthermore, justice would not be served if the centralized review had to piece together the claim when the record revealed that the legal representa- tion or translation were inadequate. Therefore, where credibility or the adequacy of legal representation and translation are in doubt, the centralized review should have the authority to refer the matter to another local panel for a new oral hearing.

Given the importance of the accurate identification of legitimate refugees, it is essential that the appointments of refugee decision-makers at all levels be other than on a patronage basis. Individuals should be appointed who have a demonstrated expertise in refugee matters. Such persons should be drawn from the community at large and their appointments should be full-time. It is advisable that the government consult with credible, non-governmental organizations with expertise in this area before making appointments. Another important consideration is that the decisionmakers be independent of the Canada Employment and Immigration Commission (CEIC) to ensure that humanitarian refugee criteria be applied exclusively. One fears that immigration considerations may be applied if the decisionmakers are or were once accountable in any way to the Commission.

A well-conceived inland refugee determination procedure could effectively deter abusers from taking advantage of Canada's traditional generosity towards the persecuted. An expeditious determination would eliminate the opportunity of long-term employment in Canada for illegitimate refugee claimants, thereby removing one of the main reasons for abuse.

All rejected claimants are not abusers, notwithstanding the position of the CEIC to the contrary. Many have fled their countries out of fear for their lives and those of their spouses and children. While they may not meet the technical requirements of the refugee definition, their fears are certainly well-founded and understandable. Consequently, it is unfair and inappropriate to label these claimants as abusers. The Canadian government should create a mechanism whereby non-refugee, humanitarian 
claims can be determined outside the refugee determination process. This mechanism will ensure that any new refugee determination procedure will not become overloaded by humanitarian claims.

Amnesty International shares the concerns of the Canadian government with respect to the abuse of the process, given that abuse impacts upon legitimate refugee claimants. However, Canada's primary concern should be the accurate identification and protection of legitimate refugees, and the deterrence of abusive claims secondary.

The Canadian government has a challenging opportunity to devise an inland refugee determination procedure that can be a model for the rest of the world. The challenge is twofold. We must have a procedure which is both expeditious and fair with competent decision-makers at all levels of the process. Otherwise, miscarriages of justice will continue. If these basic principles can be respected, then Canada will have met the challenge and will once again prove to the international community that we truly are leaders in the area of refugee policy.

Michael Schelew is Executive Member responsible for Refugee Affairs and past President of the Canadian Section (Anglophone) of Amnesty International.

\section{Profile: The Refugee Documentation Project, York University}

The Refugee Documentation Project (RDP) was established in August 1982 to ensure that a centralized body of documentation on refugees would be assembled and made available to individuals and organizations in Canada and abroad. The RDP has compiled a bibliography with over 5,000 entries on key areas of refugee-related research. It maintains a library of books and reports filling 30 metres of shelving and four filing cabinets.

In addition, the RDP supports research on refugee topics and has published a number of studies. With regard to countries of origin research, the RDP has published a firsthand report on the "Homeless, Displaced Persons and Refugees in Lebanon, 1982," which was used as a reference by the United Nations and both sides in the conflict. It also has published a brief, firsthand report on the situation of the Tamils in Sri Lanka.

In the area of settlement research, the RDP did a study of Canadian Government and non-governmental policy for bringing Indo-Chinese refugees to Canada. A major report on settlement policy led directly to the establishment of pilot projects as precursors to a new official settlement policy. The RDP also has published a major study on Unaccompanied Children in Emergencies: The Canadian Experience.

The Refugee Documentation Project coordinated the preparation of briefs to the Plaut Commission and spoke to the Association of Immigration Lawyers on status determination in Canada and other legal issues. The RDP chaired the Refugee Policy Review in 1982 and wrote a report for the Minister on priorities in the refugee area.

Earlier this year, the RDP published a study of the archival resources of the United Nations Relief and Works Agency for Palestine Refugees (UNRWA).

In addition, the Project publishes the quarterly Refuge: Canada's Periodical on Refugees.

A founding member of the Inter-
University Consortium for Refugee Research, the RDP co-sponsored with Oxford's Refugee Studies Program a workshop on "Refugees in the Twentieth Century in Europe and the Middle East" in August 1985. In May 1986 it will cosponsor, with the University of Toronto, a conference on "Canada: Land of Refugees, Land of Asylum?"

Current research projects of members of the RDP include:

\begin{tabular}{|c|c|c|}
\hline Scholar & Affiliation & Research \\
\hline Adelman, Howard & Philosophy/York U. & Palestinians and UNRWA \\
\hline Angus, William & Law/York U. & Immigration \& Refugee Law \\
\hline Basok, Tanya & Sociology/York U. & Salvadorean Refugees in Costa Rica \\
\hline Gismondi, Michael & $\begin{array}{l}\text { Social \& Political } \\
\text { Thought/York U. }\end{array}$ & $\begin{array}{l}\text { Central American Refugees in } \\
\text { Canada }\end{array}$ \\
\hline Hathaway, James & Law/York U. & $\begin{array}{l}\text { Refugee Law in Canada; } \\
\text { Comparative Refugee Law }\end{array}$ \\
\hline Lam, Lawrence & Sociology/York U. & $\begin{array}{l}\text { Adjustment of Female } \\
\text { Vietnamese-Chinese Refugees } \\
\text { in Montreal }\end{array}$ \\
\hline Lanphier, Michael & Sociology/York U. & NGOs and Refugee Resettlement \\
\hline Luciuk, Lubomyr & Geography/U. of T. & $\begin{array}{l}\text { Ukrainian Refugee Migration; } \\
\text { Canadian Refugee Policy Post } \\
\text { WW II; Afghan Refugees in Pakistan }\end{array}$ \\
\hline Mata, Fernando & Sociology/York U. & $\begin{array}{l}\text { Immigrant Satisfaction: Latin } \\
\text { Americans in Canada }\end{array}$ \\
\hline Simmons, Alan & CERLAC/York U. & $\begin{array}{l}\text { International Migration and } \\
\text { Social/Economic Transformation } \\
\text { in the Caribbean }\end{array}$ \\
\hline Van Esterick, Penny & Anthropology/York U. & $\begin{array}{l}\text { Lao \& Khmer Adaptation in } \\
\text { Toronto }\end{array}$ \\
\hline Zisman, Alex & $\begin{array}{l}\text { Social \& Political } \\
\text { Thought/York U. }\end{array}$ & $\begin{array}{l}\text { Media and the Response to } \\
\text { Refugees }\end{array}$ \\
\hline
\end{tabular}




\section{Dear Subscriber:}

As you are aware, Refuge can no longer rely on government funding and is struggling to survive on the basis of donations. Your response to our recent appeal is greatly appreciated and has made this publication possible. But we still have a long way to go to ensure continuing publication.

If each of you could get two more people to support Refuge we would have no difficulty not only continuing but expanding and improving Refuge. So please get four! A support card is printed below for your convenience.

Please remember our survival depends on your help.

Thank you again for all that you have done.

Howard Adelman

Editor
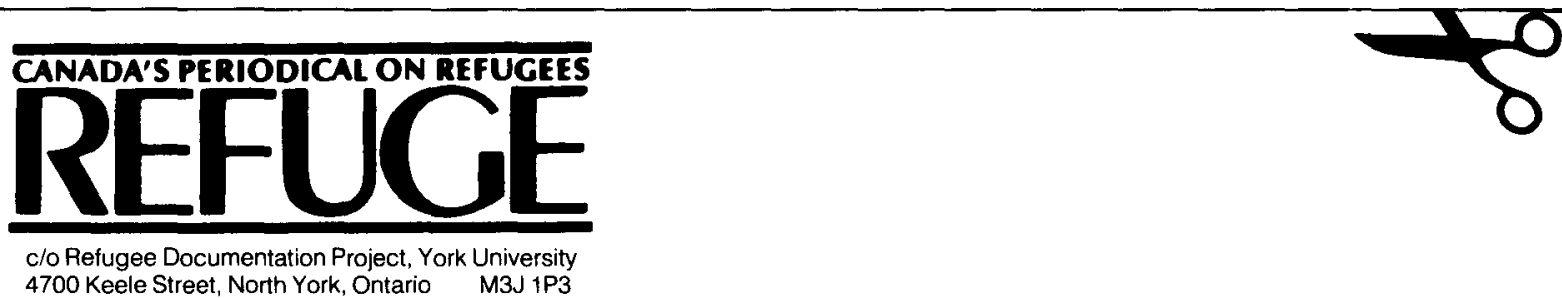

I wish to become a supporter of the Refugee Documentation Project. I understand I will receive Refuge free of charge for one year, as well as information on the research activities of the RDP. My check for \$20 (or ) made payable to the Refugee Documentation Project is enclosed.

Name Organization

Address

City Province or State

Country Postal Code 